\title{
Radio Remediated: Sissako's Life on Earth and Sembène's Moolaadé
}

\author{
by Marissa J. Moorman
}

Abstract: Remediation is a noted phenomenon in cinema studies. How it operates in African films has been less parsed. This article examines Abderrahmane Sissako's La vie sur Terre (1998) and Ousmane Sembène's Moolaadé (2004), two films with distinct approaches to the remediation of radio. I argue that postcolonial African media contexts, where national cinemas struggle (Nollywood excepted) and radio thrives, compel us to read remediation's tensions as locally rendered and politically charged. As these media interact on film they pose questions about visuality, sound, and broadcasting that fortify the film narratives and challenge media ideologies of the continent.

$\mathrm{F}$ or the past forty years, scholars have referred to African news media and other new forms of communication, like the mobile phone, as "Africa's drums." Marshall McLuhan calls radio "the tribal drum" in Understanding Media. ${ }^{2}$ Pressing electrified media forms, whether analog or digital, into "traditional" molds for the imprimatur of African authenticity reveals what Ilana Gershon calls "media ideologies." 3 Media ideologies are ideas and beliefs about the mediated communicative channels available to producers and receivers of information. ${ }^{4}$ Many people, both on and off the African continent, assume that radios, televisions, and film cameras are "foreign" technologies. This is one kind of media ideology at work. Referring to radios or mobile phones as "drums" attempts to indigenize or adopt these strange technologies into a local genealogy, and constitutes a form of remediation. For Gershon remediation is a part of media ideologies: new media are always preceded by other forms. But remediation can also be a self-conscious

1 For an older example, see William A. Hachthen, Muffled Drums: The News Media in Africa (lowa City: lowa State University Press, 1971), xiii; and, more recently, Mirjam de Bruijn, Francis Nyamnjoh, and Inge Brinkman, eds., Mobile Phones: The New Talking Drums of Everyday Africa (Leiden: Langaa and African Studies Centre, 2009).

2 Marshall McLuhan, Understanding Media: The Extensions of Man, ed. Terrence Gordon (Berkeley, CA: Gingko Press, 2011), 397.

3 Ilana Gershon, "Media Ideologies: An Introduction," Journal of Linguistic Anthropology 20, no. 2 (2010): 283-293.

4 Gershon, "Media Ideologies," 283.

Marissa 7. Moorman, associate professor of African history and of cinema and media studies, Indiana University, is author of Intonations: Music and Nation in Late Colonial Angola (Ohio University Press, 2008) and is writing the book Powerful Frequencies: Radio, State Power, and the Cold War in Angola. She is on the editorial board and blogs for Africa Is a Country, the blog that is not about famine, Bono, or Barack Obama. 
strategy deployed to challenge media ideologies. Here I argue that Abderrahmane Sissako's La vie sur Terre (Life on Earth, 1998) and Ousmane Sembène's Moolaadé (2004) remediate radio to defy the conventional media ideologies that circulate about communication practices and technologies on the African continent. In particular, I explore how these two films play out John Mowitt's refinement of a key aspect of Jay David Bolter and Richard Grusin's idea of the rivalry at the core of remediation. ${ }^{5}$ What Bolter and Grusin define as rivalry, Mowitt rethinks as betrayal. Mowitt thus evokes key film theoretical problems posed by remediation: in this case, he explores the differences between images and sound in Michael Curtiz's 1947 film The Unsuspected. ${ }^{6}$ In the films of Sissako and Sembène, when we add betrayal to the analysis, those same theoretical problems surface, as do new questions about the conditions of postcolonial film production and the stakes of postcolonial filmmaking in Africa's media rich environment.

Intensifying Remediation for the Postcolonial Context. Jay David Bolter and Richard Grusin identify a rivalry or tension in what they term "remediation":

We call the representation of one medium in another remediation, and we will argue that remediation is a defining characteristic of the new digital media. What might seem at first to be an esoteric practice is so widespread that we can identify a spectrum of different ways in which digital media remediate their predecessors, a spectrum depending on the degree of perceived competition or rivalry between the new media and the old. ${ }^{7}$

They are careful to point out that while new media have intensified this practice, remediation has been actively used in the Western visual canon for at least the past four hundred years. The scope of their work is solidly Western, and it is not by chance that they mention the tradition of "Western visual representation." 8 So what do we do, then, with films produced in a postcolonial African context, burdened with media ideologies about the continent, and so attuned, if not vigilant, to foreign technologies? ${ }^{9}$

We need something more muscular than "rivalry" to traverse postcolonial terrain. I turn to John Mowitt. Mowitt recruits Raymond Williams's concept of the residual to fortify Bolter and Grusin's rivalry. In this formulation the tension of rivalry is transformed into treason:

While elsewhere I have proposed that the concept of the residual is underdeveloped in Williams ... what it nevertheless brings to the remediation debate (above and beyond its complication of "the new" in new media) is a political valence or tonality whereby the representation of one medium

5 Jay David Bolter and Richard Grusin, Remediation: Understanding New Media (Cambridge, MA: MIT Press, 2000), 45.

6 John Mowitt, "Avuncular Listening: The Unsuspected," Recherches Semiotiques 29, nos. 2-3 (2009): 83-84.

7 Bolter and Grusin, Remediation, 45.

8 Bolter and Grusin, Remediation, 11, 45, 55, and 61.

9 See the exchange in Jean-Marie Teno's first-person narrative documentary Sacred Places (2010) between him and the djembe master Jules over the relationship between drum and cinema as storytellers. 
within another can be understood as an "interested" and thus contentious representation. In effect, what residualism allows one to hear in translation as transmutation is the oft-cited quip, "traductore, traditore," where the rivalry evoked by Bolter and Grusin takes form as betrayal, even treason. ${ }^{10}$

In this particular piece, Mowitt is not concerned with the postcolonial, but "betrayal, even treason" provides a kind of torsion, unavailable in rivalry, that is productive for thinking about how media are set in relation to one another in postcolonial Africa, and perhaps elsewhere too.

Here I use the postcolonial in the temporal sense but also in the broader sense to indicate that cultural repertoire and sensibility that accounts for the deep marks created by the epistemic and material violence of colonialism on colonized bodies, spaces, and institutions. It is the analysis of colonialism's continued plays of power and violence even after its formal departure. Treason, the betrayal of trust, imbues the postcolonial: the falsehoods of colonialism's episteme, its empty promises and treasonous ways, are always being exposed. ${ }^{11}$ And in the other direction, if we follow Homi Bhabha's terms, "the menace of mimicry is its double vision which in disclosing the ambivalence of colonial discourse also disrupts its authority." 12 Subversion, treason, of the colonial is possible. Thinking about remediation in this context requires an eye and ear to the operations of power in and through technology.

Specifically, then, I argue that Abderrahmane Sissako's Life on Earth and Ousmane Sembène's Moolaadé, in remediating radio, offer "interested" (in Mowitt's sense) representations of it. Film and radio emerge historically around the same time. With the advent of the "talkie," film integrates sound and seems to offer a more complete technology. But the workings of sound embodied in radios in Life on Earth and Mooladé operate despite maybe even to spite - film's seeming completeness. This is radio at work in Williams's "residual" capacity, as a resistant, against the grain of the dominant, element: "Certain experiences, meanings, and values which cannot be expressed or substantially verified in terms of the dominant culture, are nevertheless lived and practiced on the basis of the residue - cultural as well as social - of some previous social or institutional formation." ${ }^{13}$ Here we will think both in terms of residual media and technologies and in terms of the residual bodily and listening techniques and practices associated with them. For Mowitt, this is the whetstone on which to hone Bolter and Grusin's rivalry and focus film theory's epistemic categories. In Life on Earth and Moolaadé, I am interested in how the residual has both structural force and narrative meaning. Radio's remediation poses a challenge to media ideologies of the continent, attends to the political economic situation of postcolonial continental

10 Mowitt, "Avuncular Listening," 83.

11 I am thinking here of the character Kip, a Sikh sapper in a British army unit, in Michael Ondaatje's The English Patient. At the US bombing of Hiroshima and Nagasaki, he realizes he's been fighting for a West that will not protect him, that has, in fact, betrayed him. He then insists on being called by his Sikh name, Kirpal Singh, and shortly thereafter returns home to join the struggle for independence. Michael Ondjaatje, The English Patient (New York: Vintage Books, 1993). 
media production, and raises the vexed issue of current filmic practice relative to other media.

Remediation is a concept widely used in communication and cinema studies. ${ }^{14}$ Scholars of African cinema have taken it up less readily. ${ }^{15} \mathrm{I}$ aim to show that it is a productive concept that presses against the burden of representation of the African continent that scholars and filmmakers are assumed to shoulder and the very media ideologies that purvey such notions. Kenneth Harrow enumerates some of the "sacred cows" of African film criticism: African film rights past misrepresentations; it corrects the representations purveyed in Hollywood and the media; it represents Africa; it is the site for truth; and African film is African. ${ }^{16}$ In other words, African film and film criticism are first and foremost a representational practice and act. Pushing aside representational interpretations for remediated readings of these two films redirects analytical focus to the complexity of Sissako's and Sembène's aesthetic practices.

African Cinema and Radio: A Brief Sketch. European colonial powers introduced film for pedagogical, propagandistic, and entertainment purposes in their African colonial territories. The British Film Institute's Colonial Office opened the Bantu Educational Cinema Experiment in 1935. Financial support came from the Carnegie Institute, Roan Antelope Mines, and Mufulira Copper Mines Ltd., revealing the imperialist and capitalist interests at play. The Colonial Film Unit, with offices in each of the English African colonies, produced educational films. A film school in Accra trained Africans to assist in film production but maintained a structural dependency on the United Kingdom. Paternalistic and racist in its conception, as Manthia Diawara argues, this system, by the mid-1950s, had also passed the cost of film production to the colonies. ${ }^{17} \mathrm{~A}$ similarly paternalistic approach to filmmaking and training prevailed in the Belgian Congo, where a cinema bureau and three Christian missions engaged in film production. Their films, a number of them animated, while lauded for centering

14 Sandra Annett, "The Nostalgic Remediation of Cinema in Hugo and Paprika," Journal of Adaptation in Film \& Performance 7, no. 2 (2014): 169-180; Allan Cameron, "Zombie Media: Transmission, Reproduction, and the Digital Dead," Cinema Journal 52, no. 1 (2012): 66-89; David Novak, "Cosmopolitanism, Remediation, and the Ghost World of Bollywood," Cultural Anthropology 25, no. 1 (2010): 40-72; L. Meghan Peirce, "Remediation Theory: Analyzing What Made Quarterlife Successful as an Online Series and Not a Television Series," Television and New Media 12, no. 4 (2011): 314-325; Caroline Radcliffe, "Remediation and Immediacy in the Theatre of Sensation," Nineteenth Century Theatre \& Film 36, no. 2 (2009): 38-52; Teri Silvio, "Remediation and Local Globalizations: How Taiwan's 'Digital Video Knights-Errant Puppetry' Writes the History of the New Media in Chinese," Cultural Anthropology 22, no. 2 (2007): 285-313; and Leshu Torchin, "Mediation and Remediation: La Parole Filmée in Rithy Panh's The Missing Picture (L'image manquante)," Film Quarterly 68, no. 1 (2014): 32-41.

15 Vincent Bouchard, "Commentary and Orality in African Film Reception," in Viewing African Cinema in the TwentyFirst Century, ed. Mahir Saul and Ralph A. Austen (Athens: Ohio University Press, 2010), 95-107; Alessandro Jedlowski, "Small Screen Cinema: Informality and Remediation in Nollywood," Television and New Media 13, no. 5 (2012): 431-446; Duncan Omanga, “'Peeling Back the Mask': Remediation and Remix of Kenya's News into Popular Culture," Journal of African Media Studies 7, no. 1 (2015): 11-23; and Katrien Pype, "Remediations of Congolese Urban Dance Music in Kinshasa," Journal of African Media Studies 7, no. 1 (2015): 25-36.

16 Kenneth W. Harrow, Postcolonial African Cinema: From Political Engagement to Postmodernism (Bloomington: Indiana University Press, 2007), xi.

17 Manthia Diawara, "Sub-Saharan African Film Production: Technological Paternalism," Jump Cut 32, April 1987 (reprint 2006), 61-65. 
African content, nonetheless purveyed the cant of imperial racism and policy. ${ }^{18}$ Film production in the French colonies likewise emphasized propaganda and education with the added intention of spreading French culture and the French cinematic tradition. ${ }^{19}$

Since independence, national cinemas have, for the most part, struggled. Cognizant of the limitations of their structural and ideational inheritance and of the power of international commercial film distribution syndicates, early filmmakers and national cinema bodies fought to create oppositional institutional sites for independent practice and distribution, but to little avail. Ousmane Sembène became a proponent of cinéma engagé, a cinema at the service of the people, a cinema to critique colonial and neocolonial relations and retrograde cultural practices, an ideologically informed cinema. ${ }^{20}$ An anticolonial stance permeated film criticism as well. ${ }^{21}$

In Ghana, Kwame Nkrumah built what was then the most extensive film production infrastructure on the continent, but it was largely run into the ground by his successors. ${ }^{22}$ In Nigeria, state support for film production was thin. Television, dating from the late colonial period, had greater force and dynamism, although by the mid-1980s the state funded the training of some Nigerians in European film schools. Francophone filmmakers have survived on joint productions financed through the French Ministry of Culture and Overseas Cooperation, a state institution formed in 1961 at the dissolution of France's African empire, committed to securing work for French producers and crew members and to maintaining cultural influence in the former colonies. ${ }^{23}$ This created what Claire Andrade-Watkins calls a situation of technical underdevelopment and continued dependency on France. ${ }^{24}$ By 1975, French West Africa accounted for 80 percent of film production from the continent. ${ }^{25}$ But even today, much, if not most, of the postproduction by filmmakers from these countries is still done in France.

Portuguese-speaking filmmakers in Angola, Mozambique, Cape Verde, GuineaBissau, and São Tomé, where the Portuguese colonial state left no production facilities, had to build cinema institutions from the ground up. ${ }^{26}$ The first legislative act of

18 Ibid.

19 Ibid.

20 Harrow, Postcolonial African Cinema, 1; and Claire Andrade-Watkins, "Film Production in Francophone Africa, 1961-1977: Ousmane Sembène-An Exception," in Samba Gadjibo, Ralph H. Faulkingham, Thomas Cassirer, and Reinhard Sander, eds., Ousmane Sembène: Dialogues with Critics and Writers (Amherst: University of Massachusetts Press, 1993), 29.

21 Kenneth W. Harrow critiques the use of these nationalist and modernist frames in African film criticism and filmmaking in Postcolonial African Cinema, 22-30.

22 Diawara, "Sub-Saharan African Film Production," 61-65.

23 Akin Adesokan "African Film," in Africa, 4th ed., ed. Maria Grosz-Ngaté, John Hanson, and Patrick O'Meara (Bloomington: Indiana University Press, 2014), 238-240; Manthia Diawara, African Film: New Forms of Aesthetics and Politics (Munich: Prestel, 2010), 33-35; and Claire Andrade-Watkins, "Portuguese African Cinema: Historical and Contemporary Perspectives: from 1969 to 1993," Research in African Literature 26, no. 3 (1995): 134.

24 Claire Andrade-Watkins, "France's Bureau of Cinema: Financial and Technical Assistance between 1961 and 1977: Implications for African Cinema," Framework 38 (1992): 27-46.

25 Andrade-Watkins, "Film Production," 29.

26 Adesokan "African Film," 233-249; Fernando Arenas, Lusophone Africa: Beyond Independence (Minneapolis: University of Minnesota Press, 2011), 105-108; and Manthia Diawara, African Cinema: Politics \& Culture (Bloomington: Indiana University Press, 1992). The historical situation is obviously more nuanced than I have 
Mozambique's first president Samora Machel inaugurated the National Institute of Cinema. The institute, with a team of local and foreign filmmakers, set about creating a revolutionary film practice, filming weekly newsreels for distribution on mobile cinema vans and feature films that focused on history and anticapitalist development. Ros Gray argues that the Front for the Liberation of Mozambique government framed this as an internationalist project in which "the local and the international [were] understood as reciprocal, and cinema was recognized as having the capacity to reveal and indeed to produce those emancipatory interconnections." ${ }^{27}$ A combination of war (the Rhodesian Central Intelligence Organisation created and backed the insurgent group Mozambican National Resistance, or RENAMO), the suspicious circumstances surrounding Machel's death in a plane crash in 1986, and the official renunciation of Marxism-Leninism in 1989 weakened the National Institute of Cinema, which was hobbled almost completely by a fire in $1991 .^{28}$

Other national film projects faced economic and ideological constraints imposed by structural adjustment programs imposed in the 1980s. The state funding that had existed in some countries evaporated and film production withered. In the late 1980s video film production emerged in response to the hamstrung local conditions of production and foreign-saturated mediascapes in Ghana and Nigeria. ${ }^{29}$ Filmmakers, many trained in television, leveraged the availability of affordable new film production technologies, socioreligious changes related to image use and consumption, and the desire of audiences to see local stories on screen. ${ }^{30}$ This novel film production practice and genre development have garnered scholarly interest, not to mention popular acclaim, within and outside Nigeria. ${ }^{31}$ Carmela Garritano argues that early and sustained criticisms, often based in only a glancing knowledge of the films, "have

depicted. Diawara's history shows the differences in former French and English colonies and the diversity of film production in the colonial period. Specifically, on Portuguese-speaking African countries, see Andrade-Watkins, "Portuguese African Cinema," 134-150; on Mozambique, see Ros Gray, "Cinema on the Cultural Front: Filmmaking and the Mozambican Revolution," Journal of African Cinemas 3, no. 2 (2012): 139-160; and Gray, “'Haven't You Heard of Internationalism?': Communist Cinema in Mozambique," in Postcommunist Film—Russia, Eastern Europe and World Culture: Moving Images of Postcommunism, ed. Lars Lyngsgaard and Fjord Kristensen (Abingdon, UK: Routledge, 2012), 53-74.

27 Gray, "Cinema on the Cultural Front," 140.

28 Ibid., 157.

29 Akin Adesokan, Postcolonial Artists and Global Aesthetics (Bloomington: Indiana University Press, 2011), 83-84; Jonathan Haynes, ed., Nigerian Video Films (Athens: Ohio University Press, 2000); and Carmela Garritano, African Video Histories and Global Desire: A Ghanaian History (Athens: Ohio University Press, 2013).

30 Matthew H. Brown, "At the Threshold of New Political Communities: Some Notes on the History of Nollywood's Epic Genre," Global South 7, no. 1 (2013): 55-78; Garritano, African Video Histories; Brian Larkin, Signal and Noise: Media, Infrastructure, and Urban Culture in Nigeria (Durham, NC: Duke University Press, 2008); Birgit Meyer, "Praise the Lord . . . : Popular Cinema and Pentacostalite Style in Ghana's New Public Sphere," American Ethnologist 31, no. 1 (2004): 92-110; and Meyer "Impossible Representations: Pentecostalism, Vision and Video Technology in Ghana," in Religion, Media and the Public Sphere, ed. Birgit Meyer and Annelies Moors (Bloomington: Indiana University Press, 2006), 290-312.

31 See Lindiwe Dovey's introduction to the special issue of Journal of African Cultural Studies, where she discusses the distinctions between scholars who study African cinema and those who study video film. Dovey, "Editorial: African Film and Video: Pleasure, Politics, Performance," Journal of African Cultural Studies 22, no. 1 (2010): 1-6. See also Matthew H. Brown and Nyasha Mboti, "Nollywood's 'Unknowns': An Introduction," Journal of African Cinemas 6, no. 1 (2014): 3-9. 
functioned chiefly to produce and police an idea of what African screen media should be," constraining media ideologies. ${ }^{32}$ Importantly, Nollywood symbolizes a new kind of commercial, independent mode of cinematic production, and a novel film genre deeply marked by television. ${ }^{33}$

Pronouncements about African radio broadcasting are neither as dire nor as celebratory, even as African radio broadcasting has grown steadily across this same period. ${ }^{34}$ James R. Brennan argues that "radio, in sharp contrast [to film], revolutionized the form and possibilities of all types of communications" on the African continent. ${ }^{35}$ Colonial-era radio often rested in the hands of colonial government administrators or settlers (which was initially the case in Angola and Mozambique). Imperial and colonial broadcasting sought first to inform and entertain European populations in African countries. World War II changed the game, as Axis and Allied powers used radio in military communications and for propaganda. ${ }^{36}$ James R. Brennan notes that radios during World War II "were swollen with hostile invective of Axis powers challenging the legitimacy of British and French colonial rule." ${ }^{37}$ In the wake of the war, radio expansion on the continent grew apace with the new British and French colonial agenda of development. But liberation movements were among the savviest broadcasters on the continent. Radio in the postcolonial period thus became a cornerstone of state communications and national development.

Today, radio is the primary form of mass media consumed on the continent. Even as state broadcasters dominate, the liberalization and privatization that accompanied structural adjustment in many countries across the continent has been a boon for radio, opening space for smaller community-based and privately run radio stations to flourish. ${ }^{38}$ After all, the financial and technical overhead for radio is much lower relative to that of film production. ${ }^{39}$ Even state radio can be a site of dissent, which Harri Englund persuasively argues has been the case for critiques of local power

32 Garritano, African Video Histories, 5.

33 On the televisual aspects of the genre, see Moradewun Adejunmobi, "African Film's Televisual Turn," Cinema Journal 54, no. 2 (2015): 120-125. Jude Akudinobi notes how it has spawned a "number of "woods'" across Africa, mostly in Anglophone countries. Akudinobi, "Nollywood: Prisms and Paradigms," Cinema Journal 54, no. 2 (2015): 133.

34 Louise M. Bourgault, Mass Media in Sub-Saharan Africa (Bloomington: Indiana University Press, 1995), 68-102; Hachten, Muffled Drums, 18-23; and Sydney W. Head, Broadcasting in Africa: A Continental Survey of Radio and Television (Philadelphia: Temple University Press, 1974).

35 James R. Brennan, "Communications and Media in African History," in The Oxford Handbook of Modern African History, ed. John Parker and Richard Reid (New York: Oxford University Press, 2013), 500.

36 Brian Regal, Radio: The Life Story of a Technology (Westport, CT: Greenwood, 2005), 95-96.

37 Brennan, "Communications and Media," 501.

38 British Broadcasting Corporation, "African Media Development Initiative: Research Summary Report" (London: BBC World Service Trust, 2006), 25; Bourgault, Mass Media in Sub-Saharan Africa, 68 and 99-102; Richard Farndon and Graham Furniss, eds., "African Broadcast Cultures," in African Broadcast Cultures: Radio in Transition (Westport, CT: Praeger, 2000), 1-3; Liz Gunner, Dina Ligaga, and Dumisani Moyo, eds., "Introduction: The Soundscapes of Radio in Africa," in Radio in Africa: Publics, Cultures, Communities (Johannesburg: Wits University Press, 2011), 11; and André-Jean Tudesq, L'Afrique parle, I'Afrique écoute: Les radio en Afrique subsaharienne (Paris: Éditions Karthala, 2002), 15-17.

39 Tudesq discusses the minimal investment required to open a new radio station, in L'Afrique parle, l'Afrique écoute, 60. 
holders launched on the Chichewa-language show Nkhani Zam'maboma (News from Districts) on Malawi's public airwaves. ${ }^{40}$ Finally, the mobile phone revolution has put radios in the hands of all of those who own such a device. ${ }^{41}$ Not only do they run on radio waves, but most mobile phones contain a radio, and smartphones, a growing commodity on the continent, offer a variety of radio apps. This media convergence means that radio continues to be a vibrant medium, often packaged in a new slick form, not a dusty relic or quaint practice surpassed by more recently introduced technologies; instead, "technology is changing fast but seems to be enhancing rather than replacing radio." 42 A walk down an urban street, through a marketplace, or along a dock will find it alive with a riot of radio sounds and broadcasting in a variety of African languages. Homes, restaurants, and offices often have radios and televisions running simultaneously or play radio sound to accompany a televisual image.

Radio exerts its presence in quotidian life in a way film can only aspire to. Despite Nollywood, largely a home-video phenomenon, cinematic spaces and film production are in flux. It is not uncommon to see shuttered and abandoned cinemas across the continent. ${ }^{43}$ Moradewun Adejunmobi notes the small number of cinemas in operation currently (twelve in Burkina Faso, five in Niger, three in Namibia). ${ }^{44}$ Still, it is too easy to overstate the senescence of cinema spaces. The growth of a middle class, and the moneyed business classes in some countries, has fostered the advent of multiplexes in shopping malls in Kenya (Planet Media Cinemas), Angola (Orient Cinemas - a Brazilian company), Nigeria (Silverbird Group), and South Africa (Ster-Kinekor). The biennial Pan-African Film and Television Festival of Ouagadougou (FESPACO), founded in 1969, now screens Nollywood films, and there are a growing number of African film festivals on and off the continent. ${ }^{45}$ Neighborhood and market-based cinema houses (offering viewing from televisions connected to DVD players) bring film to the masses. ${ }^{46}$ Nonetheless, it is safe to say that film cannot rival radio's local instantiation and vibrancy, except perhaps in Nigeria. African filmmakers are well aware of the thickness of mediascapes on the ground in African countries, of their intricate, far-reaching economies, and their power-laden histories.

Harri Englund, Human Rights and African Airwaves: Mediating Equality on Chichewa Radio (Bloomington: Indiana University Press, 2011).

41 Gunner, Ligaga, and Moyo, "Introduction," 2.

42 Mary Myers, "Radio and Development in Africa: A Concept Paper" (International Research Development Centre of Canada, Ottawa, August 2008), 6.

43 Marissa J. Moorman, "Of Westerns, Women, and War: Resituating Angolan Cinema and the Nation," Research in African Literature 32, no. 3 (2001): 103-122; and Walter Fernandes and Miguel Hurst, Angolan Cinemas (Göttingen: Steidl and Goethe-Institut, 2015).

44 Adejunmobi, “African Film's Televisual Turn," 122

45 For example, the UK's FilmAfrica (http://www.filmafrica.org.uk); Dockanema, a documentary film festival in Mozambique; FESPACO (http://www.fespaco.bf/en/about-fespaco/institutional-informations); New York African Film Festival (http://www.africanfilmny.org); and Zanzibar International Film Festival (http://www.ziff.or.tz), among many others.

46 For an example, see Teno's Sacred Places; and Charles Ambler, "Mass Media and Leisure in Africa," International Journal of African Historical Studies 35, no. 1 (2002): 119. 
Radio may be a more popularly accessible mode of mass culture than film, but it is still film's residual. By remediating radio, Sissako and Sembène's films play out some of the remediation dynamics Mowitt outlines to reflect on the rich African media context. As filmmakers from former French West African colonies, Sissako and Sembène know all too well the strictures and opportunities of ongoing "French cooperation." They have found themselves enmeshed in the shift from a revolutionary cinéma engagé, associated with newly independent states and Cold War factions, to the globalizing production networks of nongovernmental organizations, former colonizers, and international foundation funding sources. While both studied film in Moscow, they did so at different moments and under distinct conditions (Sembène in 1962 and Sissako in the late 1980s and early 1990s as the Soviet Union underwent significant change). Sembène's principled, insistent stance of maintaining artistic autonomy and integrity, and independent funding after initial shocks with the Cinema Bureau, made him a symbol of cinéma engagé in terms of both content and production. ${ }^{47}$ Sissako, in contrast, considered among the continent's third generation of filmmakers, embraces diverse funding sources, including French coproduction and television. Akin Adesokan argues that this strategy has shaped Sissako's aesthetics, which he describes as the "poetics of engaged expatriation." 48 This particular relationship with French funding and its cinematic and technological legacy may have some bearing on why these two filmmakers are so intent on using radio in these two films. ${ }^{49}$

Visual and Sonic Rivalry in Life on Earth. Life on Earth is Abderrahmane Sissako's 1998 film made for the French television series 2000 vu par (2000 Seen By) (Caroline Benjo and Carole Scotta) about the passage to the new millennium as presented by ten independent filmmakers from ten different countries. ${ }^{50}$ California Newsreel, the film's US distributor, describes it as a "fictional documentary" of life in Sokolo, Mali. It is a film largely devoid of plot, a meditation on the challenges of communication. Promotional material from California Newsreel offers an overdetermined reading of the film's relation to technology: "Sissako's specific challenge therefore was to make a film about the significance of the start of the twenty-first century for people still struggling to enter the twentieth; in other words, to show Africa's simultaneous connection to and isolation from modernity, our so-called Information Age." The distributor's interpretation of the film deepens the groove of this now-tired media ideology, and stereotype, of the African continent. It resuscitates the ghosts of G. W. F. Hegel and Oxford historian Hugh Trevor-Roper, who condemned the continent to a

47 Andrade-Watkins, "Film Production," 33-36; and Diawara, African Film, 33-34.

48 Akin Adesokan, "Abderrahmane Sissako and the Poetics of Engaged Expatriation," Screen 51, no. 2 (2010): 143-160.

49 That said, radios enter into a number of other African-made films. They have various functions: efficient purveyors of plot, anachronistic archive, sign of technology and modernity, colonial trace, community link, and simultaneous synchronicity. Some films include Zézé Gamboa's O herói (2004); Djibril Diop Mambéty's Le petite vendeuse de soleil (1999); Raoul Peck's Lumumba (2000); and Moufida Tlatli's The Silences of the Palace (1994).

50 Ten films by ten up-and-coming directors shown on the Franco-German channel Arte, on November 27, 1998. Milly Buonanno, ed., Continuity and Change: Television Fiction in Europe (Luton, UK: University of Luton Press, 2000), 154. 
status outside of and behind time and the West, denying African coevalness. ${ }^{51}$ Using remediation is productive for thinking about what Sissako is doing in Life on Earth because it restores coevalness and shifts the optic from the West as a metric of "the rest" to media in relation to one another. In Life on Earth technology is not a measure of development; it is neither fetishized nor condemned. Technology is simply taken in - as Sissako's camera takes in everything after it arrives in Sokolo at the same angle, straight on, never inclined up or down. Indeed, Sissako seems much more concerned with technologies and how they facilitate, or not, communication between people and not how they place the continent, or Sokolo, on some global or millennial time line.

Radios do not appear in the film's opening, but they are alluded to. Shifting camera angles draw our attention to sound, which alternates between muffled, recorded sounds and then the introduction of natural noises. This undoes the visual as a stable referent, tugging the spectator's ear into service and recalling the very problem Mowitt advances: film's remediation of radio plays on the latter's residual technological status. Mowitt goes still further: "Part of remediation should involve the way film theoretical problematics, as it were, represent, or frame, one another. . . [P] roblematics engaging the differences between sound and images are themselves caught up in this remediation, this rivalrous residualism." "In the opening of Life on Earth, sound itself, not yet materialized in radio, raises the issue of the sound/visual relationship.

The film begins in Paris: a tilt to capture a vertical display of large ceramic ducks and then the face of the protagonist, Dramane (played by the filmmaker Abderrahmane Sissako; the character's name is a diminutive of his name), his mouth drawn in droll imitation of the ducks' beaks. A pan across a refrigerated section of cheeses and butters and shoppers' heads in the flattening, unflattering fluorescent light of commercial shopping spaces follows. In the next shots we see that it is holiday time, and we see but cannot hear a brief exchange between Dramane and a woman trying on a hat while the canned announcement of a message over a loudspeaker carries over a cut to Dramane, his gaze afar, an oversized stuffed polar bear tucked under his arm, ascending an escalator. The tones of a stringed instrument begin to call from outside the scene, and Dramane continues to look directly into the camera before it cuts to a tree. The camera zooms slowly in on the leafless branches of a massive tree against a washed-out blue sky while the plaintive sounds of a Middle Eastern stringed instrument play against the rising sounds of insects chirping and cattle braying. The screen goes black; the title appears. The chirps of insects carry over from the prior shot to this one, and woven in now are the songs of birds and the bleating and braying of animals, enriching the black screen and yellow letters with natural, worldly sounds. We have, as it were, emerged from a subterranean shopping mall of the metropolis, a land of overproduction and overconsumption, of flat colors and recorded, faded sounds death by glut and mechanization - to la vie sur Terre, life on Earth. The contrast is unmistakable, and it is manifest most forcefully in sound. Acousmatic sound pulls us

51 Johannes Fabian, Time and the Other: How Anthropology Makes Its Object (New York: Columbia University Press, 1983). See also Achille Mbembe, introduction to On the Postcolony (Berkeley: University of California Press, 2001), 1-23. 
across the visual border, the gap of the title, to another world. The sound, in Mowitt's sense, "betrays" the image, letting us know we have moved on long before any image has cued such advance for us.

Acousmatic sound is sound with a source originating outside the film frame but still part of the profilmic space. It is a cinematic staple. But acousmatic sound is also tightly bound to radio technique and history. Radio broadcasts, typically sight - and site - unseen, travel via invisible electromagnetic waves. In this sense, Sissako's use of acousmatic sound in Life on Earth evokes the radio long before it appears, embedding the "rivalrous residualism" of sound and image Mowitt described. In the opening scene of Life on Earth we move sonically and then visually from Paris to Sokolo. This is a movement to "life on Earth," away from the metropole, the seat of colonial power and the center of neocolonial economic influence. Sissako does not make Sokolo the new center - sound continues multisited - but the metropole is provincialized.

The tension between sight and sound, Paris and Sokolo, springs forward in the diegesis as we hear Dramane's voice-over reading the letter he has written to his father and watch his father reading it in Sokolo. He broadcasts his arrival in the narrative of the film, undoing the message he had sent his father in a phone call to his friend Jiddou, who then passed the message to his father in person. Once in Sokolo, radios and telephones, Aimé Césaire's texts (read on the radio or as part of the narration) and personal letters, are acts of remediation that underscore the significance of sound and communication. Acousmatic sounds remediate: they reframe scenes, giving a new interpretation to older information (Jiddou's message) or enlivening text on the radio to bring Césaire's analysis of the colonial experience into earshot and to bear on the scene.

Sissako's use of acousmatic sound allows us to consider the radio before it appears as an object. More direct remediation of radio occurs when radio objects enter the visual and aural fields. Once radios enter, they are a constant visual presence. And when the town radio starts broadcasting, the aural presence of radio permeates and shapes the film, recasting how we can think of the visual. We first glimpse a radio in the home of Dramane's father, on a table tall with books, notebooks, and scattered pamphlets, signaling the dense mediation of this space through words spoken, read, and written. When Dramane goes to the town square, radios are everywhere. Located there, too, is the local radio station, simultaneously known as Radio Sokolo, Radio Colon, and Le Voz de Riz (The Voice of Rice; Figure 1). Men gather under trees and in the shade of compound walls to sip tea and listen to radios, large and small. In the bicycle repairman's shop, his large radio sits on the ground, its speaker visible through the counterclockwise spinning of Dramane's tire spokes as it is repaired (Figure 2). Men don radios around their necks (worn like Mande amulets) as they travel on donkeys or bicycles. ${ }^{53}$ The town photographer, Kolou, listens to a small transistor.

What work does this remediation do? Sissako uses film to show us what radio cannot reveal about itself, animating the rivalry that Bolter and Grusin described. He

53 I owe this observation to Henry Drewal, from when I gave a much-earlier iteration of this paper at the University of Wisconsin-Madison in February 2013 at the Mellon Seminar on New Media and Mass/Popular Culture in the Global South. 
sets the chronos (duration) of film on the kairos (moment, or point in time) of radio; he uses film's visual duration to trump radio's aural ephemerality. $^{54}$ We see what we would otherwise only hear if we were tuning in. We see it first in the onthe-air library broadcast by Maiga (where he reads Césaire) and second in the transmission of Radio France International (RFI), when we see various local audiences and imagine the international ones hailed in the broadcast. We see the square where women dressed all in black pass by on donkeys and six men seated in the shade listen to two midsized radios. We hear radio blips:

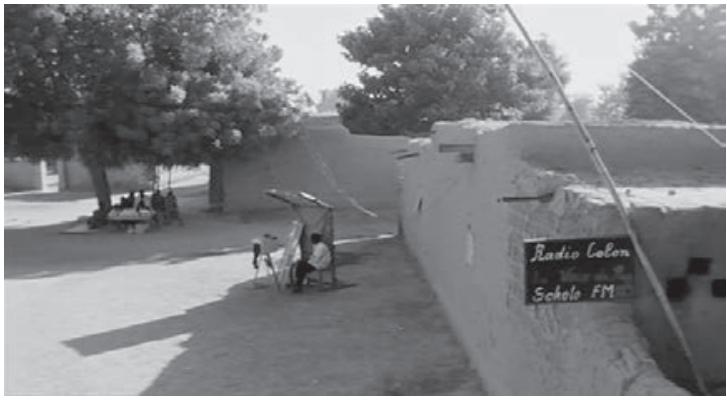

Figure 1. Sokolo Village with radio station sign and photographer in the frame in Life on Earth (La Sept Arte, 1998).



Figure 2. Radio visible through the spokes of a bicycle tire being repaired, in Life on Earth (La Sept Arte, 1998).

"It's 10h00 in Paris, 9h00 Greenwich Mean time. The news with Valérie Ohar." Then the voice of Ohar:

Good day! In fourteen hours France will change minutes, seconds, hours, months, years, and what we've all been waiting for: the century and millennium. Not all countries will change millenniums today because not all countries are on the same calendar. Those who do will celebrate in style. In Paris, thousands are expected to attend local dances and fireworks displays. Huge crowds are expected at the Eiffel tower. For one thousand days it has been counting down to the year 2000 .

Here is Benedict Anderson's homogeneous empty time hard at work in sonorous mode. ${ }^{55}$ Various locales in Sokolo are shown while we hear about celebrations at 10:00 a.m. Paris time, 9:00 a.m. universal time, in literal translation. The film camera makes this available, demonstrating its technological seniority to recover itself against acousmatic sound's early dynamism.

54 John Durham Peters, "Calendar, Clock, Tower," in Deus in Machina: Religion and Technology in Historical Perspective, ed. Jeremy Stolow (New York: Fordham University Press, 2013), 30-31.

55 Benedict Anderson, Imagined Communities (London: Verso, 1996). I have written about sonorous capital and simultaneity in chapter 5 of Intonations: a Social History of Music and Nation in Luanda, Angola, from 1945 to Recent Times (Athens: Ohio University Press, 2008). 
But radio has another rival. Radio's rival in the diegesis of the film is the telephone. The film remediates both, setting them up against each other. Woven throughout the film, people make visits to the post office to place phone calls. There we see and hear the employees listening to radio amid bureaucratic clutter and duties. If we know from the beginning that Dramane's letter rescinds the message he sent by phone call to Jiddou to deliver to his father, underscoring the temporary nature of any message, then the phone calling, radio announcements, the bicycle encounter conversations between Dramane and Nana, and the phone calls placed at the post office highlight the fragility of all communication. Bina, the local postmaster, makes a phone call for Dramane and says to him over beeps and pauses: "It's ringing in England and I'm calling Paris. . . . It's hard to reach people. It's a question of luck." At the center of the film, then, is this sense of the chance encounter and the vulnerability of all communicative acts: the desire to speak, "the desire to film Sokolo," as the narrator says, and thus this very film. ${ }^{56}$

Returning to Mowitt's insight about interested representations in the question of remediation reveals a transposition and tension, maybe even a betrayal, at work: Sissako is filming this for a television series. ${ }^{57}$ Bringing McLuhan's distinction between hot and cool media to Life on Earth, the radio stands in for film (both are "hot" media) and the telephone for television (as "cool" media). Radio successfully broadcasts to a wide public, a worldwide audience in fact, whereas the telephone is bedeviled by constant communications breakdowns. Every phone call is troubled by poor connections. In the first one the woman speaks loudly to overcome interference and a spotty connection; the camera cuts to a shot of the antenna (Figures 3 and 4). In other scenes, numbers get mixed up when they are written down or dialed. Calls placed for

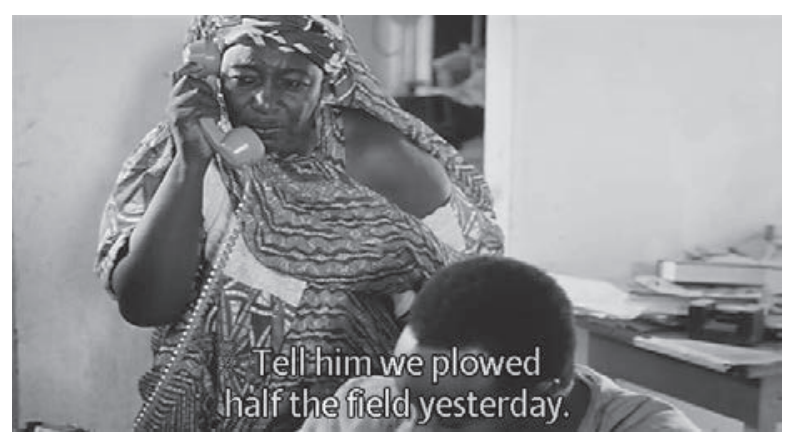

Figure 3. Woman speaking on a phone with poor reception, in Life on Earth (La Sept Arte, 1998). one destination wind up in another. In one scene, the phone company's faded and stained poster exclaims its failure: "SOTELMA: a phone in every home!" The telephone, a point-topoint communication technology, embodies bad reception or failed reception. Bad reception here indicates interference in transmission or reception. Communication by telephone always requires extra steps, often literally. When Marie calls from Paris for Dramane, Bina lifts himself from his wheelchair, grabs his crutches, and walks to Dramane's home (we've just seen Dramane pass by, but Bina has not). Nana tries to locate a man named Baï 
by calling the town where he is located and indicating that he's in the shop next to the cinema. And then she waits for someone to walk to the shop and back before a return call that never comes. On New Year's Day, still not having heard from Baï, the operator offers her a secret, well-tested strategy: cross-

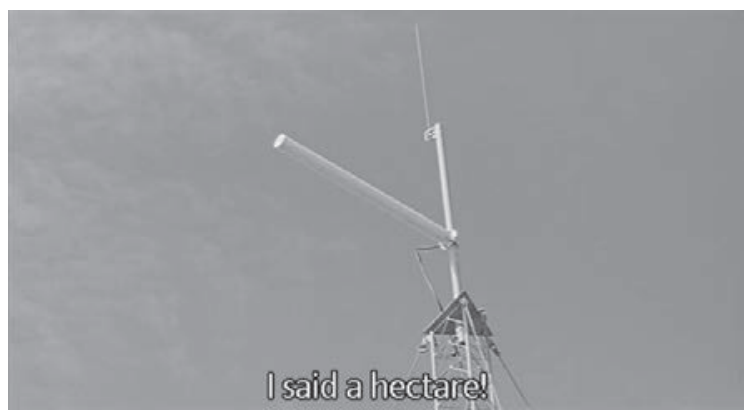

Figure 4. Shot of antenna with a woman's voice-over, underscoring that she is not being heard, in Life on Earth (La Sept Arte, 1998). transferring, with three viable and one not recommended options. Phone calling is like a game with stakes.

The state project to put a phone in every home, to privatize communication, remains an empty promise. In contrast, the community radio functions flawlessly. That said, it is run-down, but its mechanical equipment works, and, as Akin Adesokan notes, "its derelict appearance seems to reflect its usefulness." 58 Indeed, it works with precision. Even when the Bamanankan-speaking host must leave early to chase the plague of birds from the fields, he signals to the sound engineer, who plays music at that exact moment to fill in until the French-speaking broadcaster, Maiga, arrives to broadcast his on-the-air library. Under the gaze of Sissako's camera, radio is idealized as a public good. This is a jab at the conditions of production under which his particular film was produced, that is, for television, a private European channel no less. Here, then, the film camera remediates radio to both romanticize that technology, as a communications form, and point a finger at the neoliberal conditions of production that constrain life on Earth and its aesthetic representation, Life on Earth.

If the structural relation of film remediating and reflecting on radio (film showing us what radio cannot about itself) fits Bolter and Grusin's construction of sibling rivalry, albeit one that flatters and romanticizes radio, the diegetic remediation produces betrayal. Radio-film and telephone-television are set up in stark opposition. The teasing and flattery shifts to identification and is turned against the telephone, then reaches outside the narrative and frame, to point a finger at the television. In interviews, Sissako has commented that of ten filmmakers, he was the only African filmmaker chosen. He also notes he was the last filmmaker chosen. Sissako points to the structural legacy of French media production and the burden of representation and tokenism - having to be the single voice for the continent on the cusp of the millennium - it creates. That legacy resonates in these acts of remediation in the film. The tension between radio-film and telephone-television, the poetry and "usefulness" of radio's operation as opposed to the failures of the telephone to successfully communicate, betrays the attempted representational remediation (in the sense of repair or improvement) of Africa that is promised, if not necessarily delivered, in the film's production as part of this television series. 
The film camera is never represented directly. And it is not a perfect complete medium. It, too, is betrayed, in a sense, by other technologies: radio and the photographic camera. Here the "good" reception it showed us in representing radio is undermined. Older technologies betray newer ones, exposing their limits and occlusions. The juxtaposition of the visual and aural with different visual media, threaded throughout the film, undermines visuality's claim to ensure good reception. This work bolsters the narrative emphasis on the chance encounter and the fragility of communication. Bad reception, or no reception, in other words, is just as likely as good reception. More specifically, you cannot trust your senses.

Two moments of this kind of remediation warrant attention. The photographer is seen several times listening to radio. It is in his hand, close to his ear, or sitting on the top of his camera, a big yellow box built on a tripod. Throughout the film, at several points, we are asked to consider the frame within the frame, the shot, the cut, both visually and sonically. ${ }^{59}$ Early on in the film, the photographer is taking a picture of a young woman all dressed up. We see him tapping the camera box and hear clipping sounds we assume are the camera shutter, but then the shot cuts to the barber. Acousmatic sound again. He's snipping and shaping the hair of a young man. Much later, the main female figure in the film, Nana Baby (with whom Dramane crosses paths frequently) visits the photographer shortly before leaving Sokolo with her suitcase strapped on the back of her bike. We see the tailor approach the photographer, and the shot cuts to a plastic basin with a black-and-white photo of Nana Baby. He asks if her photo is ready. "There it is," responds the photographer. "I didn't know she was so sad," comments the tailor, who has fitted her, and thus has been in close proximity to her, and something about which the photographer has seemed jealous. Here the kairos of the photo reveals aspects of Nana Baby's emotional state that were lost in the accumulation of moments on film. The still-black and white, no less - strikes back, betrays the film camera.

One effect of all the visual framing - mirrors, doorways, walls - and in contrast to so much otherwise open space, is the sense of the cut, the end of the image, the creation of perspective, and what is occluded. The camera in the box, covered women and men, and life lived in semiprivate-semipublic exemplify this. This effects a delocalization of the senses: from eye to ear, sight to sound. We see Nana Baby on her bike stop to chat with Dramane as he is showering and shaving (we see his expression in a mirror). In another scene, Danté showering, covered in suds, and listening to music on the radio chats with Dramane while children dance in the alley. Then there are images of heads passing by as people walk or cycle past, their full view obscured by compound walls. The camera reminds us constantly that we cannot see everything, that vision is partial, that there is no full picture. The film camera is not all-seeing and all-knowing. Sissako thus insists that we listen carefully.

The sound editing is complex and delightful. From the moment we leave the recorded sounds of the underground shopping center in Paris, the sonic world is rich and nuanced. It is composed of analogically and digitally recorded animal, human, 
musical, and mechanical sounds, both diegetic and nondiegetic. This refers us back to the radio, the telephone, and the spoken word, to oral practice and the oral tradition. We hear balafon (a kind of xylophone), kora (a twenty-one-stringed bridge-harp), and ngoni (West African lute) played on the radio throughout the film. "Folon," sung by Salif Keita, plays at the beginning and at the end of the film. Keita hails from a long line of djeli (praise singers, storytellers, poets, historians), or griots, and all of these instruments are those associated with djeli (the Malinke caste who recount, in song, the histories of West African nobility). Aimé Césaire's texts are read on the radio, are part of Dramane's narration, and sometimes quotations from them sit still on the screen while a bass intones in the background. Words, animated and ventriloquized as speech and presented as text, become live to the eye with sound accompaniment.

These scenes of remediation expose the richness of Sokolo in sound and shape, showing the limitations of the eye and the film camera in capturing and communicating what is before them. Older and other forms of media - the radio, the photographic camera, text - expose the constraints to which the film camera is subject. In this sense, too, there is bad reception at work. But perhaps it is the very bad reception of hot media that makes them cool, that draws in the listener, the audience, and demands engagement, like Frantz Fanon's description of Algerians retransmitting broken broadcasts of the Voice of Algeria. ${ }^{60}$ Sissako employs the capacity of other media to betray film, to undercut its seniority, to open up the possibilities of new cinematic dialects: the visual, narrative, and sonic are all there, but the accent he gives each is distinct. It is perhaps for this reason that his work is so often described as poetic. Is it ironic that it is the very tension of technologies and their effects that produces the visual and sonic lyricism? Perhaps more dangerous is to suggest that film's most interesting moment might be, like radio for Mowitt or Fanon, in bad reception. ${ }^{61}$ Or when film becomes like the telephone and television - in acts of piracy that result in poor or bad reception, as Brian Larkin's work illuminates, or when it becomes more televisual, as Moradewum Adejunmobi argues has been one of the effects of Nollywood. ${ }^{62}$

Radios, Towers, and Broadcasting Bodies in Sembène's Moolaadé. Radios in Life on Earth are one among a number of other technologies that catch the eye of the camera. This is in stark contrast to radios in Ousmane Sembène's 2004 film Moolaadé. Here, they are so present and alive that they almost play a role. Radios are placed in a local genealogy of other communication practices, namely drumming, the palaver of elders (generally among men, though women are sometimes called to participate), and Islamic prayer. Moolaadé is Sembène's last feature film and was meant to be the second of a trilogy about women and everyday life (the first was Faat Kine, 2000). Set in a village in Burkina Faso, Moolaadé is the story of a society confronting its own practices of oppression, as is the case in many of Sembène's films. To paraphrase the Burkinabe filmmaker Gaston Kaboré, every society contains both injustice and the forces for 
change. ${ }^{63}$ This film deals with a practice referred to in the film as "purification" and "cutting" but otherwise known as female genital mutilation or female circumcision. Six young girls have run away from the ritual and sought the protection - moolaadé - from Collé, the second wife in the multiwife household of Ciré Bathily. Collé is known for having refused to have her daughter, Amsatou, undergo the circumcision because she herself nearly died in childbirth from the effects of the practice.

The moolaadé is an ancient, local practice. It is physically manifested in the village square where the town's first king, who transgressed the moolaadé, was killed by rebellious subjects and buried, his swollen body transmuted into an anthill. Next to the anthill stands the village mosque, built later when the village ancestors converted to Islam. On the other side of the square sits the temporary selling post of Mercenaire - an

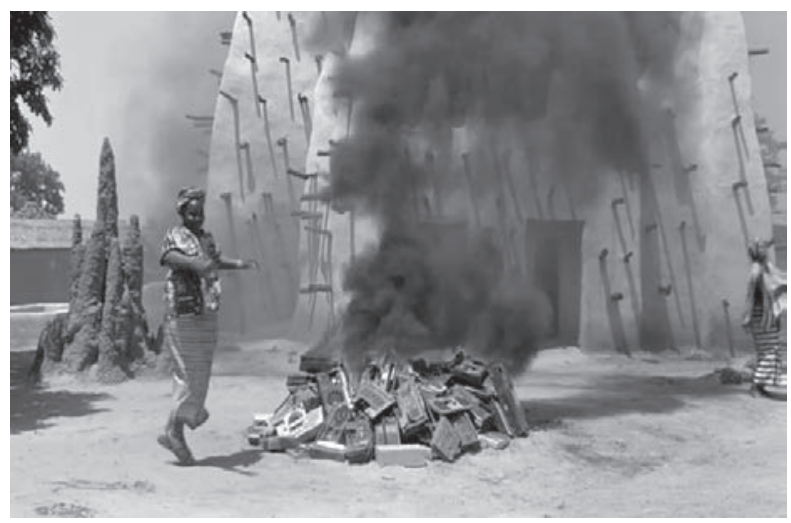

Figure 5. Three of the four poles: anthill, mosque, and radio pyre, in Moolaadé (New Yorker Films, 2004). itinerant trader, the embodiment of capitalism and globalization. The fourth pole of the square accretes over the course of the film: a pile, eventually a pyre, of radios (for three of the four; see Figure 5). It is a growing tower of Babel, the result of husbands confiscating radios from their wives in the wake of the resistance to the "purification." In effect, the village square, the scene of village conviviality, ritual, justice, debate, and exchange is marked by four towers: the ancient or traditional one of the anthill, Islam (one of the mosque's towers topped with an ostrich-egg antenna pointing to the heavens), mercenary neocolonial capitalism, and globalizing media. These represent forces with a vertical presence in society, which Sembène represents visually.

For John Durham Peters a tower is an axis mundi, a physical structure that connects heaven and earth, divine and secular power: "Every tower implies a network of communication." ${ }^{24}$ He notes that "every unit of increase on the vertical axis enormously multiplies the reach of the horizontal axis." 65 Each of the towers in this film also has horizontal reach, rendered diegetically: around the question of the moolaadé, the everyday practices of Islam and their technological mediation, new commodities and price exploitation, and the relationship of the radios and television to NGOs and outside forces. of African Cinema," Research in African Literatures 33, no. 4 (2002): 167. Ibid., 35. 
Once the film's plot has been established, the next set of scenes focalize the gendered practices of radio. Mercenaire, the traveling vendor, is the occasion for the enunciation of radio in the film. Mercenaire signals the contradictions of capitalism and globalization. Yet his character and role are complex and intriguing. His cart now unpacked, we see the cheap goods of convenience for sale: a bright array of plastic razors and basins, women's underwear, children's shorts, and rugs. On his cart sits a scale, a calculator, batteries, and stacks of bread. Next to him hangs a radio and behind him a faded development poster announcing an "International Meeting on Water" in Dakar. The cart itself is decorated with other discarded NGO posters publicizing public health education on HIV/AIDS prevention, clean water, and mother and child health-care programs. The pastiche of Mercenaire's character (former UN soldier, traveling salesman, cosmopolitan, mercenary capitalist) is reiterated in the mise-en-scène.

Mercenaire flirts with Amsatou, who has come to purchase batteries for her mother's radio. He says he'll take her as his wife and triple the bride-price already offered. She retorts, describing his offer as mercenary: "Mercenaries are people who kill women, children . . . and do coup d'états. See, I too listen to the radio!" She leaves in a huff of indignation, and we see her walking away through the goods toward the mosque, where she crosses paths with her future father-in-law, Dougoutigui, umbrella over head, accompanied by a male family member, boom box in hand. They are also on their way to purchase batteries. Mercenaire offers them either local batteries or French-made ones, more durable but more expensive. Given the importance and solemnity of listening to Koranic recitation, the end for which the batteries are purchased, they opt for the French-made ones (Sembène winks at us). Women and men use radios in different ways. Men take them out for walks; women listen to them in the compound. Women listen to the news, connecting to live programming; men listen to recordings of the recitation of the Koran, linking themselves with other communities of the faithful but not in real time. ${ }^{66}$

Quite unlike Sissako, Sembène not only puts radios in the hands of both men and women; the radios enter into the diegesis of the film in a distinct way. In Life on Earth they are represented and woven into the telling, structuring the diegesis (at times it feels like the film is a broadcast), but in Moolaade they are part of the content of the diegesis, objectified in the telling, their materiality emphasized throughout the film. Sembène's mise-en-scène is antinaturalistic. From acting style to costumes to props, the viewer's attention is constantly drawn to the fact of performance and of framing. ${ }^{67}$ Camera work reinforces this. Tilted camera angles remind us that we are swooping with the camera into the compound near the beginning of the film, for example. Radios are "propified" to a similar end. At one point, late in the film, after she calls off the moolaadé,

Debra Spitulnik's rich ethnographic work on radios points to the importance of materiality. Spitulnik, "Mediated Modernities: Encounters with the Electronic in Zambia," Visual Anthropology Review 14, no. 2 (1999): 63-84; and Spitulnik, "Mobile Machines and Fluid Audiences: Rethinking Reception through Zambian Radio Culture," in Media Worlds: Anthropology on New Terrain, ed. Faye Ginsburg, Lila Abu-Lughod, and Brian Larkin (Berkeley: University of California Press, 2002), 227-254.

67 Jared Rapfogel and Richard Porton, "The Power of Female Solidarity: An Interview with Ousmane Sembène," Cineaste (Winter 2004): 198. 


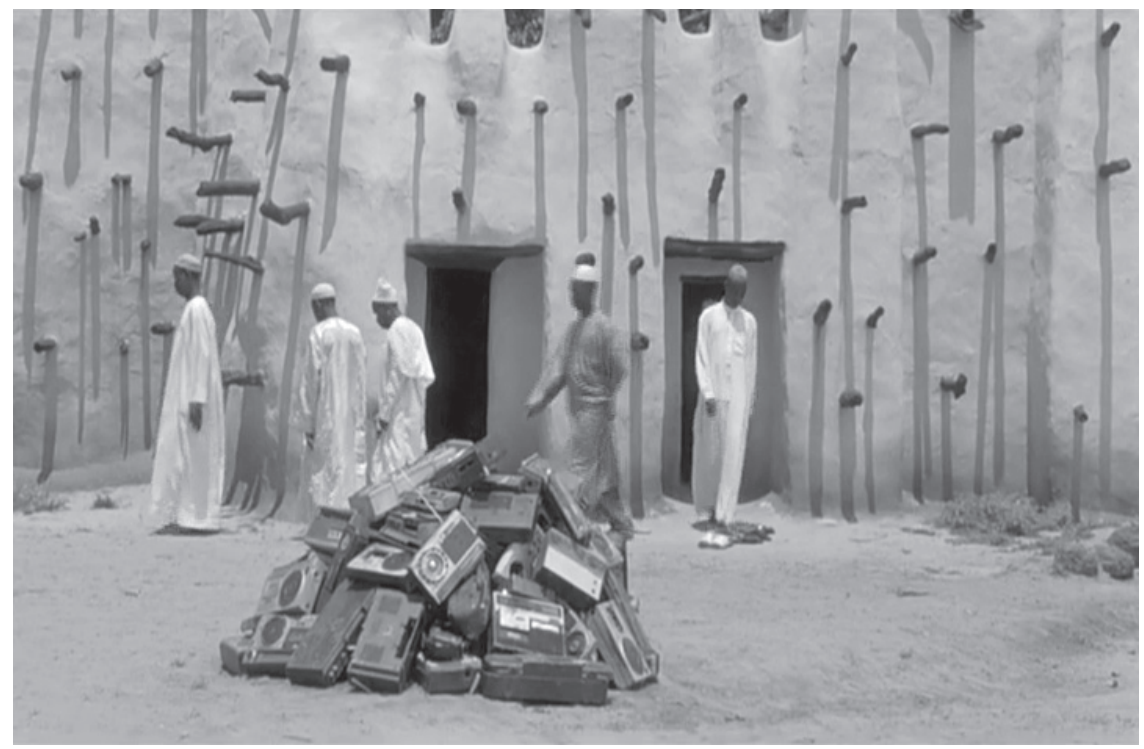

Figure 6 . The pile of confiscated radios accumulating in front of the mosque, in Moolaadé (New Yorker Films, 2004).

as the other mothers reunite with their young daughters in her compound, Colle sits with the radio on her knee as if it were a toddler.

The pile of radios is the clearest sign of the radio's materiality (Figure 6). Once Collé has declared the moolaadé, the Salindana (the sisterhood of elder women who perform the cutting ritual) complain to the village leaders, Ciré is commanded to order his wife to publicly recant the protection, and the two other girls who escaped the ritual are found dead in a well. After the girls are buried, the men talk and blame the women's radios for the trouble, and decide they will confiscate them all. We then begin to see them pile up in front of the mosque and anthill.

In the meantime, Ibrahima, the son of the village leader Dougoutigui, has returned with great fanfare from his studies in France. He arrives in a pickup truck laden with imported goods. He emerges amid the admiring tones of the djeli, is dressed in a suit and tie, and has a slim, black computer bag slung over his shoulder, the twenty-first-century equivalent of the pocket protector and an index of expertise. The morning after his arrival, drinking coffee in satin pajamas, listening to RFI, sitting next to an enormous television, his uncle tells him to turn off the radio. The elders have confiscated all the women's radios and the influence of the television is sure to be more pernicious still. "But we cannot cut ourselves off from the progress of the world!" Ibrahima replies. Ibrahima is meant to marry Amsatou, Collé's uncircumcised, or bilakoro, daughter, but instead, his father informs him he will now marry his eleven-year-old cousin. Indignant, he retorts that his marriage is his own business. If Collé and the girls around her, and increasingly the first wife in the compound, are resisting tradition, so too is Ibrahima. As the heir to the local system of power, this resistance is significant.

Meanwhile Amath, Ciré's older brother, insists that Ciré must repudiate Collé, beat her, and make her recant the moolaadé, so that the girls will be purified, including 
Amsatou. Collé is summoned to the village square and asked by the Salindana to lift the protection. Ciré begins to beat her viciously, egged on by the men and the Salindana to shouts of "Beat her! Tame her!" Women from the village, who have rushed into the square, beg Collé not to recant. The scene is alive with tension. In this beating both Ciré and Collé become antennas, temporary fixtures, sending and receiving messages. Ciré's flogging broadcasts patriarchal power in the village square. Ciré and his whip embody and transmit the power of the mosque's tower over Collé, bringing divine law down to order secular relations between men and women in patriarchal terms. Collé's body acts as another antenna. It receives the message but retransmits a different signal. It is a signal of defiance that surges and is buoyed by the insistence of the other women that she not give in, that she not utter the word, that she resist. She is the antenna for a kind of collective, community radio that spontaneously emerges in the moment, in the absence of the women's confiscated radios. As the whip beats down, her pain ripples out in waves and emboldens the women to resist. Later, they tell her, they physically felt the blows on their bodies.

In the final confrontation in the village square, relations are rearranged. Mercenaire has been killed after intervening to stop Ciré's beating of Collé (vultures flying overhead signal his murder). One pole, then, has disappeared. As men leave the mosque and head to the square for the weekly palaver, they set fire to the pile of radios, and a scream is heard. The women who gathered at Colle's to honor her and to console the mother who tricked her daughter away to have her cut at the last moment and then lost her appear in the square. The Salindana return with the "purified" girls, other women show up, and women returning from collecting firewood enter, passing what is now a pyre of radios. Among them is Sanata, the female djeli, emboldened to action, ready to broadcast the new women's message and proclaim Collé a warrior as she goes to confront the men. Sanata and Collé lay the knives they have confiscated from the Salindana in front of the men. Sanata sings Collé's praises: "You are more valiant than men!" Collé calls the men out for their fear of the radios. They accuse her of contravening Islam and tradition. She responds: "Purification is not required by Islam. The Grand Imam said it on the radio. Every year millions of women go for pilgrimage to Mecca. All have not been cut." Here she invokes live religious transmission to supersede recorded recitation in the name of the highest local Islamic authority. Collé and Sanata collect the knives and throw them on the pyre shouting, "Wassa! Wassa!" to denote their joy. Ciré and his son Balla leave, defying Amath, now in support of Collé. Amsatou approaches Ibrahima, who rises to leave and is confronted by his father. When he asserts again that his marriage is his own business, his father smacks him on the shoulder with his umbrella. Ibrahima says, "It is easy to hit a son. But the era of the little tyrant is over. Forever. I will turn the TV on." He joins Amsatou, who announces that she is and will remain bilakoro. The camera cuts to an overhead shot of the burning radios and the lens follows the black smoke up in front of the mosque to its highest tower and the ostrich egg sitting atop it. Then we cut to an aerial antenna (Figure 7) - and the credits roll. All the while, the haunting voice of song bridges one frame to the next.

The poles of the square have been disrupted, if not completely rearranged. The ending is both clear and inconclusive: a new order is imminent, even if exactly what 


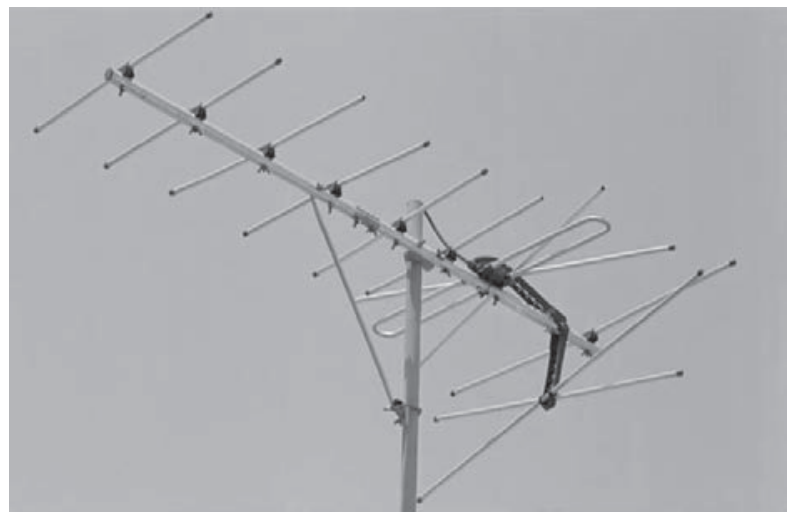

Figure 7. The aerial antenna in the closing shot of Moolaadé (New Yorker Films, 2004).

foreign than any other, that its politics will be a question of practice. Here the television is not the rival but the equal of the radio in the access it offers to other worlds and ideas. It symbolizes connection to the outside.

The television is never on in the course of the film. Its image never rivals that of the film's. It is an idea, potentiality, pure symbol. Radios, however, function and intervene in everyday life in Moolaadé. Radio transmissions here, as in Life on Earth, are troublingly smooth. In Moolaadé, when gendered power disrupts, gendered solidarity intervenes (the first wife gives Collé an old radio, tied up with red string and full of bugs, when Collé's radio has been confiscated). Radio transmission is never disrupted. Radios blare even in the pyre. Collé touches her tongue to batteries to test their liveness (Figure 8), and in the beating scene she becomes a transmitter of women's resistance, quite

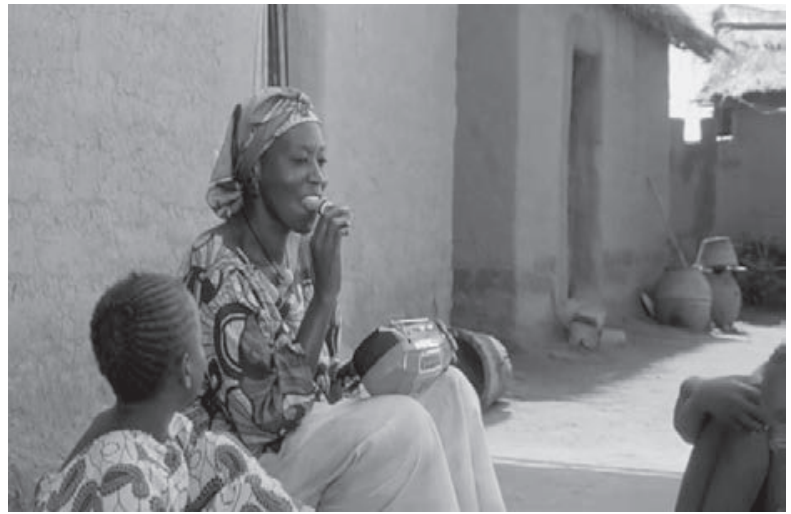

Figure 8. Collé tests a battery to see if it is good, in Moolaadé (New Yorker Films, 2004). literally embodying the futility of censorship, picking up where the radios left off. In fact, because her resistance precedes the role of radio in the diegesis, radio is first an antenna of the body, extending and broadcasting Collé's resistance (already a retransmission of the collective will of the runaway girls). ${ }^{68}$ Bodies and technologies are coextensive; technology is embedded in everyday life and living. The body constitutes a kind of media, in a circuit with other media forms, itself constantly remediated. 
If the radio and television are not in apparent tension in the diegesis of the film, the radio rivals and may even betray film. But first, as in Life on Earth, film establishes a technological seniority vis-à-vis radio in this visual telling. It represents aspects of the radio that the radio cannot communicate about itself - its materiality, its coextension with the human body, and its implication in both vertical and horizontal systems of power. Like Sissako's romanticized vision of the radio, Sembène's remediation of the radio treats it unproblematically. This might be read as condescending, the ultimate assertion of film's power and the denial of rivalry. Yet sound seems to work autonomously, raising questions about the image just the same. While the film celebrates the potential liberatory practices of media, if radio can stand in for film as another hot medium, it might also be asking, quite against its intentions, whether film (and specifically African film, the engaged kind that Sembène so heartily advocated) has fulfilled that liberatory function. This then is a kind of betrayal.

Remediation and African Cinema. In Life on Earth, the remediation of radio (and the use of sound to symbolize radio) operates to overturn Western, and sometimes African, media ideologies that imagine Africa as outside of modernity or Western time. The residents of Sokolo are linked into "the world," but they don't necessarily care about the turn of the millennium, for example. Yet through the emphasis on seamless broadcasting and good reception, the fiction the film camera tells of the radio as its stand-in is inevitably undone (betrayed, if we follow Mowitt) by the artful work of sound and the still photograph, which show the limits of the moving image.

Remediation of radio, then, does at least two things in this film. First, in Bolter and Grusin's sense, as telephone's or television's rival and film's stand-in, in the context of the history of cinema on the continent, it offers a critique of the neoliberal conditions of production in the postcolonial context for many African filmmakers, not just Sissako. Second, it performs a betrayal. Insofar as sound, acousmatic sound and sound more generally, troubles the visual, it undermines film's assumed technological seniority. This offers Sissako new modes of storytelling.

Sembène remediates radios and shows their total integration in this village's life. They are so much a part of the society, so vital, that a radio screams when the pile is lit on fire. Radios are understood to transmit Collé's resistance and are confiscated; bodies become transmitters, transforming into community radios when those other radios have been taken. This transformation, or rather permeability between body and technology, proves more dangerous than external broadcasts. In this scenario, no technology is foreign. It only extends the power and creativity of the human body and mind that picks it up, becomes part of a communications complex that is both technological and physical. ${ }^{69}$ Here it is worth a return to Williams's category of the residual. In essence, what we see in Moolaadé are residual techniques and bodily practices associated with the radio technology that, following Williams, are alternative and oppositional to the dominant culture. Is Sembène asking us to consider what has happened to the liberatory filmic practices of cinéma engagé? Are they available as a 
resistant form of residual practice, or have they become archaic, in Williams's sense, completely absorbed into the dominant and just an empty sign?

Both Sissako and Sembène make radios a part of everyday life in these two films. The manner of doing so is different, but the point is the same: technology is visibly integrated, it's opened up and part of things, not hidden and deadening like the underground shopping mall lighting in the opening of Life on Earth. In this act of exposure, they throw the question back at film, where we never see the camera. Sissako does this with radio, sound, and photography and Sembène with radio and the television antenna; they draw the viewer's attention back to the film camera as such and then point outside the frame. At the same time, the work remediation does in these films challenges media ideologies about the African continent to show that there is not so much a struggle over technologies as a conversation about them. to Fohn Nimis and the Mellon Seminar on New Media and Mass/Popular Culture in the Global South at the University of Wisconsin-Madison for the invitation to present this work in its initial form in February 2013; to Premesh Lalu and the Centre for Humanities Research, who read and discussed it in Fuly 2013; and to Drew Thompson and the Sound and Affect Workshop at Bard College for the invitation to present it in a later version in March 2015. 